\title{
MARKET STRUCTURE AND EFFICIENCY PERFORMANCE OF ASEAN BANKS
}

\author{
Rossazana Ab-Rahim ${ }^{1}$, Vimal Prakash Rao Subramaniam² \\ and Sonia Kumari Selvarajan ${ }^{3}$
}
${ }^{1}$ Faculty of Economics \& Business, Universiti Malaysia Sarawak, Malaysia E-mail: arrossazana@unimas.my
${ }^{2}$ Faculty of Economics \& Business, Universiti Malaysia Sarawak, Malaysia E-mail: vimalprakashrao@gmail.com
${ }^{3}$ Faculty of Economics \& Administration, Universiti Malaya, Malaysia
E-mail: soniakumari@um.edu.my

\begin{abstract}
The aim of this study was to investigate market structure and efficiency performance of the ASEAN banking market during the study period of 2011 - 2016. In order to assess the market structure of commercial banks in ASEAN, the Herfindahl-Hirschman index (HHI) was used while the efficiency performance which consists of technical efficiency, pure technical efficiency and scale efficiency were measured using Data Envelopment Analysis (DEA). The results showed that the banking sector in Malaysia, Thailand and Philippines are moderately concentrated while the market structure of Singapore is highly concentrated, and the least concentrated banking market is Indonesia. On this note, the HHI results indicated that banks in Malaysia, Thailand and Philippines are operating in a monopolistic market and oligopolistic in the Singapore banking market. Generally, the most efficient banks were found in Thailand, Malaysia and Singapore with regard to technical efficiency scores. In the context of the sources of efficiency, the results of the study suggest that ASEAN banks are more scale efficient than pure technical efficiency. The findings imply that the bank management should target to utilize the banks inputs at the optimum level in order to keep their performance at the efficiency frontier.
\end{abstract}

Keywords: market structure, efficiency, ASEAN banks

ARTICLE INFO

\section{Article History:}

Received: 13 March 2020

Accepted: 3 July 2020

Published: 31 August 2020 


\section{INTRODUCTION}

Following the 1997 Asian financial crisis and the 2008 sub-prime mortgage crisis, the Association of South East Asian Nations (ASEAN) banking reform policy has changed the structure of the ASEAN banking market profoundly. ASEAN is one of the fastest-growing regions in the world and the banking sector plays a crucial role in the economic development of these countries. The above-mentioned crises suggest that a sound financial system is crucial in order to ensure the stability of the economy of the countries. In order to recover the losses incurred during the crises, ASEAN has liberalised its economy to promote efficiency and competition in the banking systems. The aftermath of the crisis led to various measures to reform the banking sector including recapitalization, consolidation, and reconstruction of the banking sector in ASEAN countries. Over the years, the ASEAN banking sector has shown impressive development in line with the motive to establish an ASEAN Community. The idea of an ASEAN Community is underpinned by three main pillars: ASEAN Economic Community (AEC), ASEAN Security Community and ASEAN Socio-Cultural Community. The main goal of AEC is integration of regional economies of ASEAN members (Lee \& Fukunaga, 2014). To achieve this regional integration, AEC has listed the key characteristics and elements: (i) a single market and production base, (ii) a highly competitive economic region, (iii) a region of equitable economic development and (iv) a region fully integrated into the global economy (ASEAN, 2008).

ASEAN banks are motivated to follow Basel III $^{1}$ requirements for changes in terms of form of capital, liquidity framework and funding ratio while encouraging concentration in the banking sector. The restructuring of the ASEAN banking sector is based on (i) ASEAN central banks pushing commercial banks to consolidate to achieve financial stability and (ii) implementation of the Banking Integration Framework by 2020. The idea of an ASEAN banking Integration Framework (ABIF) is to increase competition in the banking sector and improve efficiency through external factors and regulations to operate at the current economic scale (Chan, Koh, Zainir, \& Yong, 2015). To achieve ABIF's goals, the characteristics of the ASEAN's banking sector must go through changes in terms of financial integration, privatisation and deregulation, mergers and acquisitions,

1 Basel III refers to measurement developed by Basel Committee on Banking Supervision to strengthen the regulation, supervision and risk management of banks. 
financial reforms and foreign bank penetration. Apart from that, central banks need to enforce prudential regulatory framework standards, revising regulations on limits of borrowers from the non-bank financial institutions and risk management to strengthen the banking institutions and improve regulatory framework and supervision (Khan, Kutan, Ahmad, \& Gee, 2017). Banking integration will contribute to both economic growth and financial inclusion because a more integrated banking sector will increase the competition between the banks across ASEAN countries. This competition will indirectly lead to better services, trade and investment between the ASEAN countries. On the other hand, past historical data has shown that competition is to be blamed to trigger an increasing risk-taking activity, most likely to hurt the economy. That is why it is meaningful to analyse ASEAN banking competition and efficiency comparatively. In this regard, there is a grey area in the literature regarding the ability of the conventional theories to explain the relationships between market structure and efficiency in countries with risky environments and different economic and financial conditions, as in the ASEAN banking market. The reformation of structure in the ASEAN banking market in order to achieve the ABIF goals are reasonably questionable.

Thus, the present study offers insights into the banking performance by estimating market concentration and market structure as well constructing efficiency scores of the ASEAN banks. This paper is structured as follows: the next section presents the review of past studies, the subsequent section provides an overview on data and methodology and finally, the results and discussion section follow by a conclusion section.

\section{LITERATURE REVIEW}

The link between market structure and bank performance can be explained by two competing hypotheses which are the Structure-conduct-performance (SCP) Hypothesis and the Efficient Structure (ESH) Hypothesis. Based on the CSP Hypothesis, a large percentage of market share among a few firms will foster collusion among firms in the industry (Samad, 2008). Hence, from the perspective of the SCP hypothesis, there is a positive relationship between market concentration and performance. Hence, a high concentration ratio, will lead to high profitability gain by firms. This is due to the fact 
that in highly concentrated markets, collusive behaviour increases as the market share of the market is concentrated only on a few firms. Hence, these firms will enjoy high profitability because they can impose a higher price on their products.

However, the SCP Hypothesis has been challenged by the Efficient Structure (ESH) Hypothesis. There are several limitations in the SCP hypothesis and the most notable one is the reliability of high profitability as the performance proxy. Contrary to the SCP Hypothesis, the ESH hypothesis suggests that banks' superior performance is not due to market concentration but because of the banks' superior efficiency (Smirlock, 1985). Demsetz (1973) is the main proponent of the efficient structure (ES) paradigm. Based on ES paradigm, the superior profits enjoyed by the firm in a concentrated market is due to economies of scale and the consequences of the firm superior efficiency in larger firms. The efficient structure paradigm also highlights that firms that have high efficiency in terms of technology and cost can easily capture market share by lowering their price (Samad, 2008). Under the efficient structure paradigm, there are two other hypotheses which are the x-efficiency (ESX) hypothesis and the scale efficiency (ESS) hypothesis. The x-efficiency (ESX) hypothesis assumes that the superior profitability enjoyed by the firm is due to production technology and superior management that allows firms to reduce their cost and gain more profits (Berger, 1995). On the other hand, the scale efficiency hypothesis (ESS) emphasized more on the level of scale economics. According to the ESS hypothesis, firms which operate at the scale efficient level will have lower costs per unit, thus, increasing profitability gain (Gajurel \& Pradhan, 2011).

Several past studies offer support to the SCP hypothesis such as, Bhatti and Hussain (2010) who suggested that market concentration determined the profitability of Pakistani banks while Gajurel and Pradhan (2011) found the relationship between market structure and performance of Nepalese banks can be explained using the structure-conduct-performance (SCP) hypothesis. Nabieu (2013) also suggested that banks in concentrated markets gained higher profits in the Ghanian banking industry. The findings showed that market concentration and market share significantly determined the profitability of the banking sector in Ghana. Other studies such as Bello and Isola (2014) confirmed the existence of the SCP hypothesis in the Nigerian banking sector and Al-Jarrah (2010) provided support to the SCP hypothesis. 
Additionally, Kamau and Were (2013) confirmed the SCP hypothesis in the Kenyan banking sector.

On contrary, Samad (2008) favoured the ESH hypothesis in the context of the Bangladeshi banking market. The results suggest that efficiency played a crucial role in determining the performance of the Bangladesh banks. In this vein, Sahile, Tarus, and Cheruiyot (2015) also suggested that the performance of the Kenyan banking sector can be explained by the ESH hypothesis. Results from a study conducted by Mensi and Zouari (2011) on the Tunisian banking sector for a study period from 1990 to 2005 using the Data Development Analysis (DEA) favoured the ESH hypothesis. The result of the mentioned study is also supported by Seelanatha (2010) who used the DEA to investigate the relationship between market structure and performance in the Sri Lankan banking sector. The regression results showed that efficient operation of banking firms are vital in order to obtain a high profitability and a better net interest margin. Behname (2012) showed the market concentration which measured using HHI results in a negative impact on profitability. Kunwar (2018) found that market concentration has a negative impact on the Nepalese commercial bank performance. Hence market power has a positive influence on profitability. However, Bashir, Yugang, and Hussain (2019) show that weak banking lending channels reflect great concentration and less competition.

Nguyen and Stewart's (2013) study on 48 Vietnamese commercial banks did not support both the SCP Hypothesis and the ESH in explaining the relationship between market structure and performance of the Vietnamese banking sector. During the period of the study from 1999 to 2009, the main strategies of the large Vietnamese banks were to raise capital, loans, assets, deposits, branch network and reduce non-performing loan (NPLs). Thus, revenue, interest, income and profit before tax were not the most propriety mission of the banks.

On the other hand, Ab-Rahim and Chiang (2016) conducted a study to investigate the relationship between market structure and bank performance in the Malaysian banking sector using DEA for a sample period 2000 to 2011. The results of the study provide evidence to support the ESH. The coefficient of market share is statistically significant when the ratio of profit before tax to shareholder's fund (ROE) acts as the dependent variable. Hence, an 
increase in market share leads to an increase in banks' profitability. Results from the study conducted by Abduh and Idrees (2013) on Islamic banks or windows in Malaysia using the panel data regression technique showed a positive and significant relationship between profitability and market concentration, hence, confirming that market structure has a positive impact on growth of Islamic banks in Malaysia. Yudaruddin (2015) showed that the ESH is the best hypothesis to explain the relationship between market structure and performance in the Indonesian banking sector. Concentration negatively affects the performance of MENA banks (Gonzalez, Razia, Bua, $\&$ Sestayo, 2019). Based on Khan and Hanif (2019) the banking sector in Pakistan support the ES paradigm with a weak association between market structure and bank performance. The efficiency and the competition level of banks in ASEAN-5 countries were found to be relatively high, and can be classified as monopolistic where each bank competes by diversifying their products or segments (Astuti \& Saputra, 2019). According to Khan, Ahmad and Chan (2018) the banks are profitable partially through collusion or monopoly rents, explains that the profitability of the bank is highly related to bank concentration. In Sino-ASEAN regions China followed by Malaysia and Singapore are contributing most to the efficiency frontier. The results indicate that much of the variation in the efficiency of banking markets in the Sino-ASEAN region is due to the geographical location and country-specific factors (Banna, Shah, Noman, Ahmad, \& Masud, 2019).

In short, there are two main competing hypothesis which can explain the link between market structure and performance. Based on previous literature, there are mixed results on which hypothesis best explains the relationship between market structure and bank performance. Some scholars support the structure-conduct-performance while others favour the ESH. There are limited number of studies on the market structure of the banking sector of ASEAN countries; hence, the main objective of this study was to investigate the market structure and performance of the banking sector in ASEAN countries.

\section{METHODOLOGY}

This study covered 78 bank observations over the study period of 2011 2016. The largest number of banks covered by the study were from Indonesia 
(22), followed by Cambodia (21), Thailand (15), Malaysia (7), Vietnam (6), the Philippines (3), Singapore (3), and Brunei (1). To maintain consistency across countries, the analysis included only commercial banks. The banklevel data used were taken from BankScope spreadsheets published by Bureau Van Dijk (BVD), which publishes corporate information and business intelligence as well as Orbis Bank Focus database. All financial variables reported are in nominal values of US dollar (million) to facilitate comparison over time; all the variables were deflated by the consumer price index to obtain real values, with 2011 as the base year. This study employed data envelopment analysis to measure the efficiency performance of the banking sector, and the Herfindahl-Hirschman Index (HHI) to measure market concentration.

The selected inputs for this study were deposits, fixed assets, personnel expenses and the outputs were loan and other earning assets based on previous studies by Ab-Rahim (2015); Wu, Ting, Lu, Nourani, and Kweh (2016). In general, the focus of this study was to examine the process of ASEAN commercial banks, which have similar products and services and examine the banks as an intermediation approach. The intermediation process is transforming the inputs (deposits, fixed assets and personnel expenses) to generate outputs (loans and other earning assets) and generate income. Basically, deposits represent the source of funds in the short term while fixed assets include buildings and offices that can be used in the long term. Personnel expenses represent staff to produce intermediates and generate income (interest based or non interest-based income). The DEA analysis enables measure of banks performance in terms of scale, pure technical efficiency and technical efficiency. There are three main advantages of using the DEA (Ayadi \& Ellouze, 2013); firstly, DEA provides a high degree of flexibility because it does not require us to choose a functional form of the borders that links the inputs and output levied to all banks in the sample. Next, the DEA permits easy decomposition of technical efficiency into pure technical efficiency and scale efficiency and overall efficiency into the technical efficiency and allocative efficiency when the input prices are included. Lastly, scores which are obtained through the DEA can provide an aggregate score which indicates the efficiency of each bank in relation to a set of compatible banks. 


\section{Variable Measurement}

\section{Efficiency}

The main non-parametric method, DEA, was introduced by Charnes, Cooper, and Rhodes (1978) and it is an analytical tool used to measure relative efficiency of firms throughout the process of transforming inputs into outputs. The efficiency score is obtained by taking the maximum ratio of weighted outputs to weighted inputs. This measurement allows multiple outputs and inputs to be reduced to single "virtual" input $\left(x_{i}\right)$ and single "virtual" output $\left(y_{i}\right)$ by optimal weighs. This study utilized the variable returns to scale model (Banker, Charnes, \& Cooper, 1984) as firms in practice may face either economies or diseconomies of scale. Additionally, the input-oriented DEA was employed in this study as the domestic commercial banks dwell well on the sources of input waste (Isik \& Hassan, 2003). To measure the efficiency for each bank, the ratio of all inputs was computed, such as ( $\left.u^{\prime} y i / v^{\prime} x i\right)$ where $u$ is an $M^{*} 1$ vector of output weights and $v$ is a $\mathrm{K}^{*} 1$ vector of input weights. To select optimal weights, the following mathematical programming problem is specified as:

$$
\begin{aligned}
& \min \left(u^{\prime} y i / v^{\prime} x i\right), \\
& u, v \\
& u ' y i / v^{\prime} x i \leq 1, j=1,2,3 \ldots, N, \\
& u, v \geq 0
\end{aligned}
$$

The formulation has a problem of infinite solutions and therefore, the constraint $\mathrm{v}^{\prime} \mathrm{xi}=1$ is imposed, which leads to:

$$
\begin{aligned}
& \min \left(\mu^{\prime} y i\right) \\
& \mu, \varphi \\
& \varphi>x i=1 \\
& \mu^{\prime} y i-\varphi{ }^{\prime} x j \leq 0, \quad j=1,2,3 \ldots, N, \\
& \mu, \varphi \geq 0
\end{aligned}
$$

where the notations are changed from $\mathrm{u}$ and $\mathrm{v}$ to $\mu$ and $\varphi$ in order to reflect the transformations.

Using the duality in linear programming, an equivalent envelopment form of this problem can be derived: 
$\min \theta$,

$\Theta, \lambda$

$\mathrm{yi}+\mathrm{Y} \lambda \geq 0$

$\Theta x \mathrm{i}-\mathrm{X} \lambda \geq 0$

$\lambda \geq 0$

where $\theta$ is a scale representing the value of the efficiency, score for the ith bank which will be in the range between 0 and $1 . \lambda$ is a vector of $N^{*} 1$ constants. The linear programming has to be solved $\mathrm{N}$ times, once for each bank in the sample. In order to calculate efficiency under the assumption of VRS, the convexity constraint $\left(\mathrm{N} 1^{\prime} \lambda=1\right)$ was added to ensure that an inefficient bank is only compared against banks of a similar size and provides the basis for measuring economies of scale within the DEA method.

\section{Market Structure}

The Herfindahl-Hirschman index (HHI) was used to measure the market concentration. HHI can be defined as sum of square of market share of each firm competing in a defined geographic market and then summing up the square (Al-Muharrami, Matthews, \& Khabari, 2006).

$$
H H I=\sum_{i=1}^{n} s_{i}^{2}
$$

where $s_{i}$ is the market share of firm $i$ in the market and $N$ is the number of firms. The HHI value ranges from 0 to 10 000. High $\mathrm{HHI}$ indicates low competition and conversely, low HHI indicates high competition. The higher the number of banks in the market, the lower the value of HHI, ceteris paribus (Fu \& Heffernan, 2009). The HHI also takes into account the number of banks and inequality of market share. Thus, HHI value of 10 , 000 exhibited that the market is monopoly whereas HHI value which near to zero indicates that the market is nearly perfect competition.

\section{RESULTS AND DISCUSSION}

The concentration index functions as a benchmark for the evaluation of the market. Concentration ratio is often used for public policy and measuring banking structure. The HHI has a crucial part in the enforcement process of antitrust laws in the banking sector. The concentration index plays an 
important role in determining the characteristic of the banking market, perceptions of the relative impact on large and smaller banks on competition in a market and impact of the size distribution and number of banks. HHI reflects the entry or exit of a bank into the markets, measurement of market behaviour of banks, and determine the influence of the market changes. In other words, a big player in the market will influence or force the small to act competitively or the other way around.

Table 1 presents the Herfindahl-Hirschman Index (HHI) of ASEAN banks over the period between 2011 and 2016. HHI can be categorized into three types: HHI up to 1500 is a remarkably competitive and concentrated market, HHI up to 2500 is commonly viewed as a moderately concentrated market and HHI of more than 2500 reflects a highly concentrated market. The combination of the ASEAN's banking sector showed a variance of concentration ratio over the period.

Table 1: Herfindahl-Hirschman Index (HHI) of ASEAN Banks

\begin{tabular}{ccccccccc}
\hline Year & Brunei & Cambodia & Indonesia & Malaysia & Philippines & Singapore & Thailand & Vietnam \\
\hline 2011 & 10000 & $1,180.00$ & $1,541.37$ & $1,893.33$ & $5,486.16$ & $3,408.21$ & $1,171.08$ & $1,850.51$ \\
2012 & 10000 & $1,052.01$ & $1,500.16$ & $1,750.15$ & $5,450.29$ & $3,395.44$ & $1,182.30$ & $1,907.79$ \\
2013 & 10000 & $7,889.95$ & $1,478.22$ & $1,770.94$ & $5,241.41$ & $3,399.54$ & $1,175.09$ & $2,031.93$ \\
2014 & 10000 & 7,804 & $1,535.30$ & $1,804.82$ & $5,265.40$ & $3,405.14$ & $1,217.18$ & $2,163.71$ \\
2015 & 10000 & 7,862 & $1,506.38$ & $1,814.11$ & $5,336.42$ & $3,407.62$ & $1,207.90$ & $2,238.30$ \\
2016 & 10000 & 912.07 & $1,577.62$ & $1,950.48$ & $7,964.26$ & $3,399.38$ & $1,286.42$ & $2,368.92$ \\
Mean & 10000 & $4,450.17$ & $1,523.18$ & $1,830.64$ & $5,790.66$ & $3,402.56$ & $1,206.66$ & $2,093.53$ \\
\hline
\end{tabular}

Based on Table 1, the concentration ratio for Brunei, the Philippines and Singapore showed their banking sector to be a highly concentrated market. Meanwhile, Vietnam showed a moderately concentrated market. However, the remaining countries, Indonesia, Malaysia and Thailand showed a competitive environment. Moreover, the concentration ratio of Indonesia, Malaysia, the Philippines, Thailand and Vietnam showed an upward trend over the years. In contract, Cambodia and Singapore showed a decline in trend over the years. Nevertheless, the degree of concentration of Cambodia, the Philippines and Vietnam showed significant changes in the overall market. In this case, Cambodia showed a drastic increase from 2011 to 2015 and decreases in year 2016; this may be caused by the new banks entry in the market, thus reducing the market concentration. All the same, the Philippines and Vietnam showed a gain in market concentration over the period. 
Tables 2 shows a comparison between technical efficiency (TE), pure technical efficiency (PTE) and scale efficiency (SE) for ASEAN banks over the years 2011 to 2016. The technical efficiency (TE) based on Charnes et al., (1978) used the CCR model under the assumption of constant return to scale (CRS). Technical efficiency, which can be decomposed into pure technical efficiency (PTE), based on Banker et al., (1984) used the BCC model under the assumption of variable return to scale (VRS) and scale efficiency (SE) to measure the distance between the VRS frontier and CRS frontier.

Table 2: Technical Efficiency of ASEAN Banks

\begin{tabular}{ccccccccc}
\hline Year & Brunei & Cambodia & Indonesia & Malaysia & Philippines & Singapore & Thailand & Vietnam \\
\hline 2011 & 20.55 & 17.62 & 19.13 & 29.33 & 27.85 & 24.42 & 34.42 & 18.99 \\
2012 & 21.29 & 20.49 & 20.67 & 32.62 & 13.01 & 24.16 & 33.14 & 17.31 \\
2013 & 24.86 & 22.35 & 21.72 & 34.03 & 13.00 & 25.90 & 34.45 & 17.86 \\
2014 & 24.62 & 24.27 & 21.56 & 32.77 & 15.06 & 26.43 & 34.53 & 18.17 \\
2015 & 19.68 & 25.55 & 21.17 & 38.42 & 16.04 & 24.94 & 32.29 & 19.48 \\
2016 & 15.96 & 27.50 & 20.10 & 27.29 & 20.40 & 25.64 & 26.50 & 20.38 \\
Mean & 21.16 & 22.96 & 20.73 & 32.41 & 17.56 & 25.25 & 32.56 & 18.70 \\
\hline
\end{tabular}

The results in Table 2 indicate that ASEAN banks have been characterized with large asymmetry between banks of an overall average technical efficiency (TE). Brunei showed a range between $15 \%$ to $24 \%$, Cambodia showed a range between $17 \%$ to $27 \%$, Indonesia shows a range between $19 \%$ to $21 \%$, Malaysia showed a range between $27 \%$ to $38 \%$, the Philippines showed a range between $13 \%$ to $20 \%$, Singapore showed a range between $24 \%$ to $26 \%$, Thailand showed a range between $26 \%$ to $34 \%$ and Vietnam showed a range between $17 \%$ to $20 \%$. On average, the production of the ASEAN banks has underutilized their input, which causes waste of input.

According to the results, Brunei only used 24\%, Cambodia only used $27 \%$, Indonesia used 21\%, Malaysia used 38\%, the Philippines used 20\%, Singapore used $26 \%$, Thailand used $34 \%$ and Vietnam used $20 \%$ of their input (Deposit, Fixed Asset, Personnel) in order to produce output (Loan and Other Earning Assets). The ratio of TE inefficiency of ASEAN banks suggests that, in order to produce output at an optimal scale instead of the current inefficient frontier, best practices must be adopted, and input usage of the respective countries must be reduced by at least: Brunei $76 \%$, Cambodia 
$73 \%$, Indonesia $79 \%$, Malaysia $62 \%$, the Philippines $80 \%$, Singapore $74 \%$, Thailand $76 \%$ and Vietnam $80 \%$.

Table 3: Pure Technical Efficiency of ASEAN Banks

\begin{tabular}{ccccccccc} 
Year & Brunei & Cambodia & Indonesia & Malaysia & Philippines & Singapore & Thailand & Vietnam \\
\hline 2011 & 20.55 & 25.36 & 76.96 & 57.00 & 37.72 & 86.12 & 57.19 & 75.69 \\
2012 & 21.29 & 29.27 & 83.60 & 66.21 & 17.45 & 88.07 & 55.25 & 79.34 \\
2013 & 24.86 & 29.25 & 86.67 & 66.63 & 17.08 & 92.25 & 57.89 & 81.18 \\
2014 & 24.62 & 27.89 & 86.80 & 70.07 & 20.46 & 94.94 & 57.60 & 86.09 \\
2015 & 20.76 & 28.55 & 87.55 & 74.86 & 22.47 & 93.34 & 54.72 & 93.24 \\
2016 & 16.49 & 30.96 & 84.06 & 79.15 & 32.14 & 95.12 & 51.54 & 95.72 \\
Mean & 21.43 & 28.55 & 84.27 & 68.99 & 24.55 & 91.64 & 55.70 & 85.21 \\
\hline
\end{tabular}

Table 3 shows a large asymmetry between banks of overall average pure technical efficiency (PTE) and scale efficiency (SE). Brunei showed a range between $16 \%$ to $24 \%$, Cambodia showed a range between $25 \%$ to $30 \%$, Indonesia showed a range between $76 \%$ to $84 \%$, Malaysia showed a range between $57 \%$ to $79 \%$, the Philippines showed a range between $17 \%$ to $37 \%$, Singapore showed a range between $86 \%$ to $95 \%$, Thailand showed a range between $51 \%$ to $57 \%$ and Vietnam showed a range between $75 \%$ to $95 \%$.

According to the results, Brunei utilized 24\%, Cambodia utilized 30\%, Indonesia utilized 86\%, Malaysia utilized 79\%, the Philippines used 37\%, Singapore utilized 95\%, Thailand utilized 57\% and Vietnam utilized 95\% of their input (Deposit, Fixed Asset, Personnel) in order to produce output (Loan and Other Earning Assets). The ratio of PTE inefficiency of ASEAN banks suggests that, in order to produce output at an optimal scale instead of the current inefficient frontier, best practices must be adopted, and input usage of the respective countries reduced by at least: Brunei $76 \%$, Cambodia $70 \%$, Indonesia $16 \%$, Malaysia 21\%, the Philippines 63\%, Singapore 5\%, Thailand 43\% and Vietnam 5\%. 
Table 4: Scale Efficiency of ASEAN Banks

\begin{tabular}{ccccccccc} 
Year & Brunei & Cambodia & Indonesia & Malaysia & Philippines & Singapore & Thailand & Vietnam \\
\hline 2011 & 100 & 76.47 & 25.23 & 59.62 & 80.85 & 28.38 & 66.79 & 30.56 \\
2012 & 100 & 79.72 & 24.89 & 52.96 & 82.69 & 27.45 & 66.95 & 22.04 \\
2013 & 100 & 84.35 & 25.12 & 54.85 & 83.97 & 28.11 & 65.52 & 22.15 \\
2014 & 100 & 88.25 & 24.91 & 52.59 & 82.65 & 27.86 & 65.68 & 21.30 \\
2015 & 94.83 & 90.96 & 24.12 & 53.66 & 81.58 & 26.74 & 66.06 & 20.94 \\
2016 & 96.81 & 92.10 & 23.89 & 36.81 & 74.84 & 26.98 & 59.30 & 21.32 \\
Mean & 98.61 & 85.31 & 24.69 & 51.75 & 81.10 & 27.59 & 65.05 & 23.05 \\
\hline
\end{tabular}

Based on Table 4, Brunei showed a range between $94 \%$ to $100 \%$, Cambodia showed a range between $76 \%$ to $92 \%$, Indonesia showed a range between $23 \%$ to $25 \%$, Malaysia showed a range between $36 \%$ to $59 \%$, the Philippines showed a range between $74 \%$ to $83 \%$, Singapore showed a range between $26 \%$ to $28 \%$, Thailand showed a range between $59 \%$ to $66 \%$ and Vietnam showed a range between $20 \%$ to $30 \%$. According to the results, Brunei utilized $100 \%$, Cambodia utilized $92 \%$, Indonesia utilized 25\%, Malaysia utilized 59\%, the Philippines used 83\%, Singapore utilized 28\%, Thailand utilized $66 \%$ and Vietnam utilized $30 \%$ of their input (Deposit, Fixed Asset, Personnel) in order to produce output (Loan and Other Earning Assets).

This study employed the Herfindahl-Hirschman Index to measure the market structure of the ASEAN banking sector. The Herfindahl-Hirschman Index measures the ratio of the assets of the country's banks to the total banking assets. Herfindahl-Hirschman Index captures the political influence of the financial sector. The concentration index for ASEAN banking sector is 3787.17; the result shows that the ASEAN banking sector is a highly concentrated market. Cambodia and the Philippines' concentration ratios are higher than average compared to the ASEAN banking sector concentration ratio, while other countries such as Thailand, Indonesia, Malaysia, Vietnam and Singapore's concentration indexes were lower than the ASEAN banking sector index.

Foer and Resnikoff (2014) laid out the idea of maintaining the level of competition in order for banks to be more efficient and not waste resources. A higher level of competition forces banks to utilize resources and reduce instability of the financial sector. In contract, the policy of mergers and acquisitions create high level of concentration market lead in to less 
competition, while a highly concentrated market will lower deposits rate and higher loan rates, causing the market to not fully utilize their resources (Evans, Healey, Nehme, \& Nicholls, 2015). The financial sector in many countries practices oligopolistic with less competition; the oligopolistic market structure is creating moral hazards and excessive risk taking. A highly concentrated market operates in an oligopolistic market and avoids price competition. Less competition causes a higher concentration in the market and reduces any merger to monopolize the market (Simatele, 2015).

The DEA results are the decomposition of technical efficiency into pure technical efficiency and scale efficiency. Technical efficiency generally reflects efficiency of banks in utilizing the resources, where lower technical efficiency reflects that banks are not fully utilizing the resources. Meanwhile, pure technical efficiency indicates managerial efficiency in practicing the best or worst practice to gain profits. Higher pure technical efficiency reflects that the management adopts best practices to improve performance. Scale efficiency mainly shows the operation at an optimal scale or economies of scale (increasing return to scale and decreasing return to scale). The average ASEAN banking sector performance was $23.92 \%$ for technical efficiency, $57.54 \%$ for pure technical efficiency and $57.14 \%$ for scale efficiency. The results of this research conclude that the ASEAN banking is not efficient enough to transform input to output to earn, causing wastage.

The empirical results show that banks are only utilizing $23.92 \%$ of the resources to generate income or profits. This means that banks are wasting $76.08 \%$ of their resources. By reducing the resources and diversifying services, efficiency and performance will increase. The efficiency score of the ASEAN banking sector under pure technical efficiency and scale efficiency is $57 \%$. This indicates that with the current practice, the ASEAN banking sector is only utilizing the source to generate income, while with better practice; the proceedings can improve the efficiency of the banking sector. Improvement of technologies and regulatory body enhance the performance of the banking sector over time. Besides that, most of the ASEAN banks are inefficient because of the restrictions by government, which hinder the benefits of economics of scale (Dong, Hamilton, \& Tippett, 2014). 


\section{CONCLUSION}

In general, the results of the competition and efficiency suggest a negative link between pure technical efficiency and banking competition. The negative relationship between efficiency and competition corroborates the efficient-structure (Demsetz, 1973) and the quiet-life hypotheses (Hicks, 1935). The efficient-structure hypothesis postulates that banks with superior management strategies, better technologies, and highly skilled personnel harnessed those attributes to maximize profit. Efficient banks increased their market share at the expense of inefficient banks. Similarly, efficient banks also benefit from economies of scale due to increased bank size. As the market becomes concentrated, banks can exploit their market power with a resultant trade-off between efficiency and competition. The non-competitive market permits bank managers to enjoy a "quiet life," where costs are not kept under control. This results in decreased competition.

Overall, this study presents important evidence on the link between banking competition and banking efficiency in developing countries, particularly in the ASEAN banking markets. Theoretically, intense competition compels firms to put more effort to improve their efficiency. With little or no competition, firms tend to enjoy the quiet life by taking customers for granted and making no effort to enhance their efficiency and productivity. By ensuring only the most competitive and innovative firms stay in the market, competition improves consumer welfare. Competition benefits customers by making firms more efficient and inducing them to compete on price, improve the quality of their services, and innovate more. Nevertheless, the impact of competition depends on many factors such as the nature and structure of the industry. Additionally, this study offers evidence that the impact of competition on banking efficiency varies by type of bank efficiency at work in the banking industry. Based on the research finding, bank management should target to utilize their inputs at an optimum level in order to keep their performance at the efficiency frontier. The ASEAN banking sector is operating at a minimum level, in generating income with their resources. The banking sector can be advance with better practice, technologies advancement and dynamic interferences of regulatory bodies to enhance the performance of the banking sector over time. 


\section{ACKNOWLEDGEMENT}

This work was supported by Universiti Malaysia Sarawak [grant numbers F01/SpMYRA/1676/2018].

\section{REFERENCES}

Abduh, M., \& Idrees, Y. (2013). Determinants of Islamic banking profitability in Malaysia. Australian Journal of Basic and Applied Sciences, 7(2), 204-210.

Ab Rahim, R. (2015). Ranking of Malaysian commercial banks: Superefficiency data envelopment analysis (DEA) Approach. Asian Academy of Management Journal of Accounting \& Finance, 11(1), 123-143.

Ab-Rahim, R., \& Chiang, S. N. (2016). Market structure and performance of Malaysian banking industry. Journal of Financial Reporting and Accounting, 14(2),158-177.

Al-Jarrah, I. M. (2010). The market structure-profit relationship in the Jordan's banking industry. Administrative Science, 37(1), 251-261.

Al Muharrami, S., Matthews, K., \& Khabari, Y. (2006). Market structure and competitive conditions in the Arab GCC banking system. Journal of Banking and Finance, 30(15), 3487-3501.

Association of Southeast Asia (ASEAN). (2015). ASEAN Banking Integration. Retrieved from http://asean.org/storage/images/2015/O ctober/outreachdocument/Edited\%20ASEAN\%20Banking\%20 Integration\%20Framework.1.pdf

Astuti, U. H. W., \& Saputra, P. M. A. (2019). Efficiency and Competition in Banking Industry: Case for ASEAN-5 Countries. Scientific Annals of Economics and Business, 66(2), 141-152.

Ayadi, I., \& Ellouze, A. (2013). Market structure and performance of Tunisian banks. International Journal of Economics and Financial Issues, 3(2), 345-354. 
Banker, R. D., Charnes, A., \& Cooper, W. W. (1984). Some models for estimating technical and scale inefficiencies in data envelopment analysis. Management Science, 30(9), 1078-1092.

Banna, H., Shah, S., Noman, A., Ahmad, R., \& Masud, M. (2019). Determinants of sino-ASEAN banking efficiency: How do countries differ? Economies, 7(1), 13-40.

Bashir, U., Yugang, Y., \& Hussain, M. (2020). Role of bank heterogeneity and market structure in transmitting monetary policy via bank lending channel: Empirical evidence from Chinese banking sector. PostCommunist Economies, 1-24.

Behname, M. (2012). The compare of concentration and efficiency in banking industry: Evidence from the OPEC countries. Eurasian Journal of Business and Economics, 5(10), 15-24.

Bello, M., \& Isola, W. A. (2014). Empirical analysis of structure-conduct performance paradigm on Nigerian banking industry. The Empirical Econometric and Quantitative Economics Letter, 3(3), 24-34.

Berger, A. N. (1995). The profit-structure relationship in banking - Tests of market-power and efficient-structure hypotheses. Journal of Money, Credit and Banking, 27(2), 404-431.

Bhatti, G. A., \& Hussain, H (2010). Evidence on structure conduct performance hypothesis in Pakistani commercial banks. International Journal of Business and Management, 5(9), 174-187.

Chan, S.-G., Koh, E. H., Zainir, F., \& Yong, C.-C. (2015). Market structure, institutional framework and bank efficiency in ASEAN 5. Journal of Economics and Business, 82(C), 84-112.

Charnes, A., Cooper, W. W., \& Rhodes, E. (1978). Measuring the efficiency of decision making units. European Journal of Operational Research, 2(6), 429-444.

Demsetz, H. (1973). Industry structure, market rivalry, and public policy. The Journal of Law and Economics, 16(1), 1-9. 
Dong, Y., Hamilton, R., \& Tippett, M. (2014). Cost efficiency of the Chinese banking sector: A comparison of stochastic frontier analysis and data envelopment analysis. Economic Modelling, 36(11), 298-308.

Evans, C. M., Healey, D., Nehme, M., \& Nicholls, R. (2015). Competition in Financial Services. Retrieved from https://papers.ssrn.com/sol3/paper s.cfm?abstract_id=2666851

Foer, A. A., \& Resnikoff, D. A. (2014). Competition policy and "too big" banks in the European Union and the United States. The Antitrust Bulletin, 59(1), 9-30.

Fu, X. M., \& Heffernan, S. (2009). The effect of reform on China's bank structure and performance. Journal of Banking and Finance, 33(1). $39-52$.

Gajurel, D. P., \& Pradhan, R. S. (2011). Structure-performance relation in Nepalese banking industry. International Conference on Economics, Business and Management, 4(1), 25- 31.

Global Economic Data, Indicators, Charts \& Forecasts (2018). Retrieved from https://www.ceicdata.com/en

González, L. O., Razia, A., Búa, M. V., \& Sestayo, R. L. (2019). Market structure, performance, and efficiency: Evidence from the MENA banking sector. International Review of Economics \& Finance, 64(C), 84-101.

Hicks, J. R. (1935). Annual survey of economic theory: The theory of monopoly. Econometrica: Journal of the Econometric Society, 3(1), $1-20$.

Isik, I., \& Hassan, M. K. (2003). Financial deregulation and total factor productivity change: An empirical study of Turkish commercial banks. Journal of Banking \& Finance, 27(8), 1455-1485.

Kamau, A., \& Were, M. (2013). What drives banking sector performance in Kenya? Global Business and Economics Research Journal, 2(4), 45-59. 
Lee, C., \& Fukunaga, Y. (2014). ASEAN regional cooperation on competition policy. Journal of Asian Economics, 35, 77-91.

Khan, H. H., Kutan, A. M., Naz, I., \& Qureshi, F. (2017). Efficiency, growth and market power in the banking industry: New approach to efficient structure hypothesis. The North American Journal of Economics and Finance, 42(C), 531-545.

Khan, H. H., Ahmad, R. B., \& Chan, S. G. (2018). Market structure, bank conduct and bank performance: Evidence from ASEAN. Journal of Policy Modeling, 40(5), 934-958.

Khan, M. H., \& Hanif, M. N. (2019). Empirical evaluation of 'structureconduct-performance' and 'efficient-structure' paradigms in banking sector of Pakistan. International Review of Applied Economics, 33(5), 682-696.

Kunwar, K. (2018). Market structure and performance of commercial banks: Empirical evidence from Nepal. Journal of Business and Management, $5,33-41$.

Mensi, S. \& Zuori, A. (2011). Bank industry and efficiency: The revisited model to intermediary hypotheses. Journal of Environmental Research, 2(1), 23-36.

Nabieu, G. A. A. (2013). The structure, conduct and performance of commercial banks in Ghana. European Journal of Business and Innovation Research, 1(4), 34-47.

Nguyen, T. N. \& Stewart, C. (2013). Concentration and efficiency in the Vietnamese banking system between 1999-2009. Journal of Financial Regulation and Compliance, 21(3), 268-283.

Sahile, S. W. G., Tarus, D. K. \& Cheruiyot, T. K. (2015). Market structure performance hypothesis in Kenyan banking industry. International Journal of Emerging Markets, 10(4), 697-710. 
Samad, A. (2008). Market structure, conduct and performance: Evidence from the Bangladesh banking Industry. Journal of Asian Economics, 19(2), 181-193.

Seelanatha, L. (2010). Market structure, efficiency and performance of banking industry in Sri Lanka. Banks and Bank System, 5(1), 20-31.

Simatele, M. (2015). Market structure and competition in the South African banking sector. Procedia Economics and Finance, 30, 825-835.

Smirlock. M. 1985. Evidence on the (non) relationship between concentration and profitability in banking. Journal of Money Credit and Banking, 17(1), 69-83.

Wu, Y. C., Ting, I. W. K., Lu, W. M., Nourani, M., \& Kweh, Q. L. (2016). The impact of earnings management on the performance of ASEAN banks. Economic Modelling, 53(C), 156-165.

Yudaruddin, R. (2015). Market structure, conduct and performance: Evidence from Indonesia banking industry. Jurnal Ekonomi dan Keuangan, 19 (3), 299-317. 